\title{
Effects of Forage Availability on Grazing Behavior of Heifers
}

\author{
DAVID L. SCARNECCHIA, ANASTASIOS S. NASTIS, AND JOHN C. MALECHEK
}

\begin{abstract}
Effects of decreasing availability of crested wheatgrass (Agropyron desertorum and Agropyron cristatum) on grazing time and biting rate of Angus heifers were investigated. In the first year of the study, as standing crop decreased from 474 to $170 \mathrm{~kg}$ dry matter/ha, grazing time increased from 517 to $203 \mathrm{~min} / \mathrm{day}$, while biting rate increased from 56 to $64 \mathrm{bites} / \mathrm{min}$. In the second year, as standing crop decreased from 919 to $144 \mathrm{~kg}$ dry matter/ha, grazing time increased from 380 to $656 \mathrm{~min} /$ day while biting rate increased from 37 to 50 bites/min. Grazing times were similar to those reported in the literature for pastures having much higher levels of available forage. Although grazing times may be correlated with available forage, comparison of grazing times under different pasture conditions are not meaningful unless considered along with other forage and animal factors. On crested wheatgrass pastures, maximum biting rates occurred at lower levels of available forage than reported on tropical pastures.
\end{abstract}

There have been many studies on the grazing behavior of domestic livestock (Arnold and Dudzinski 1978). Most have been conducted in temperate or tropical pastures with standing crops above those normally occurring under semiarid conditions. There is little information on grazing times and biting rates for cattle grazing mature standing forage at standing crops below $1,000 \mathrm{~kg}$ dry matter (DM)/ ha. The feeding behavior of cattle under these conditions should be established to better understand energy expenditures and production of livestock grazing on semiarid ranges. Behavioral data are also needed to formulate theories on feeding strategies and tactics of livestock.

The objectives of this study were:

1. To determine the relationship between available forage and both grazing time and biting rate of Angus heifers at low standing crops.

2. To examine how these relationships were affected by seasonal differences in the forage.

The study was conducted in conjunction with a nutritional study (Nastis 1979) which also examined effects of forage quality and standing crop on forage intake.

The entire standing crop in the present study was physically available to the heifers and was considered to be available forage. Therefore, the terms standing crop and available forage are used synonymously in this paper. All standing crops are reported on a dry matter basis.

Effects of decreasing standing crop on grazing time and biting rate have been reported by other researchers. Hein (1935) qualitatively described an increase in grazing time by beef steers as standing crop decreased. Other investigators have reported quantitative increases in grazing time with decreasing forage availability (Atkeson et al. 1942, Hodgson 1933). Arnold (1960), working with sheep, reported a linear increase in foraging time from 7.0 to $10.3 \mathrm{~h} /$ day when forage availability decreased from 3,000 to $1,000 \mathrm{~kg} / \mathrm{ha}$. In a later paper Arnold (1964) suggested that grazing time of sheep

\footnotetext{
Authors are assistant professor, Department of Forestry and Range Management Washington State University, Pullman 99164-6410; assistant professor, School of Forestry and Natural Environment, University of Thessaloniki, Thessaloniki, Greece and professor, Department of Range Science, Utah State University, Logan 84322. Published with approval of the Director, Utah Agricultural Experiment Station, as Journal Paper 2950.

Manuscript accepted September 24, 1984
}

decreased at forage availabilities below $560 \mathrm{~kg} / \mathrm{ha}$. Cattle grazing time decreased at availabilities below $3,360 \mathrm{~kg} / \mathrm{ha}$.

Hafez (1975) summarized studies of biting rate in cattle; rates ranged from 50 to $80 \mathrm{bites} / \mathrm{min}$. Chacon and Stobbs (1976) reported that the biting rate of cattle increased from 56 to 62.4 bites/ $\mathrm{min}$ and 51.4 to $59.4 \mathrm{bites} / \mathrm{min}$ as available forage decreased from 7,200 to $1,500 \mathrm{~kg} / \mathrm{ha}$ and 3,900 to $2,400 \mathrm{~kg} / \mathrm{ha}$, respectively.

Because grazing time and biting rate are readily measurable variables, changes in these variables with decreasing forage availability might be used to make range management decisions such as when to move livestock from pasture. Before such applications are possible the relationships between forage availability, grazing time, and biting rate at low. standing crops must be accurately described.

\section{Study Area and Methods}

The study was conducted during the summers of 1977 (trial 1) and 1978 (trial 2) on the Utah Agricultural Experiment Station Tintic Valley Experimental Research Unit near Eureka, in westcentral Utah. Elevation of the area is $1,650 \mathrm{~m}$. Over the past 45 years, precipitation at Eureka (approximately $10 \mathrm{~km}$ from the study site), has averaged $400 \mathrm{~mm}$ with nearly even seasonal distribution. Precipitation on the study site was 339 and $603 \mathrm{~mm}$ during 1977 and 1978 , respectively.

Two pastures served as experimental areas. Vegetation in both pastures was predominantly of the crested wheatgrass complex (Agropyron desertorum and A. cristatum) with lesser amounts of western wheatgrass (Agropyron smithii). During trial 1, a 28-ha pasture was grazed by 20, 1.5-year-old Angus heifers obtained from the cooperating rancher. From 9 August until 18 September, this pasture was stocked at a rate of 1.0 animal-unit-months (AUM)/ ha. During trial 2, 10 ha of uniform area in an adjacent pasture were fenced and grazed by 16 experimental animals and, periodically, by 18 other put-and-take animals, all similar to those used in trial 1 . The additional animals were used to achieve desired levels of forage utilization. The 10-ha pasture was grazed from 9 August until 29 September at a stocking rate of $3.7 \mathrm{AUM} / \mathrm{ha}$.

Prior to initiation of grazing trials 6 heifers were selected and trained to wear vibracorders (Stobbs 1970). Animals were moved to the study area 5 days before the beginning of trial 1 for conditioning to crested wheatgrass. Before trial 2, 10 days of conditioning were allowed, following recommendations of Church (1971). Animals had free access to water and salt-mineral licks during both trials.

In trial 1,10 of the 20 experimental animals received an average of $0.5 \mathrm{~kg}$ daily of cottonseed meal as a protein supplement. Three of the animals fitted with vibracorders received supplement. Animals receiving supplement were fed individually, as recommended by Wagnon (1965). No supplement was fed in trial 2. Animal weights were recorded at the start of both trials and every 10 days during each trial.

Grazing times were recorded on 72-hr vibracorder disks. Partial day recordings were not included in analysis of grazing times.

During each trial, biting rates were ocularly determined for the 6 heifers carrying vibracorders. Each morning and evening, a stopwatch was used to measure a 5-minute time interval during which 
all bites were counted. Timing was interrupted when heifers ceased grazing or when they walked with heads raised. Heifers used for these observations were accustomed to being handled and observed and were apparently undisturbed by the observer.

Available forage biomass was determined every 10 days during trial $I$ and every 5 days during trial 2 by harvesting and weighing herbage within stratified-random $1.0-\mathrm{m}^{2}$ plots. During trial 1,100 such plots were sampled in the 28-ha pasture; during trial 2, 35 were sampled within the 10-ha pasture. Plants were clipped at approximately $1.0 \mathrm{~cm}$ above ground level. Samples were oven-dried for 24 $h$ at $105^{\circ} \mathrm{C}$ and weighed to determine total biomass. In both years, regrowth within each recording period was measured by protecting 30 clipped plots with exclusion cages at the beginning of each period and reclipping herbage at the end of the recording period.

Plant height and species frequency were recorded during both trials. Two plants occurring in or near predetermined positions of the $1-\mathrm{m}^{2}$ sampling ring were selected for height measurements and composition estimates. Species of these plants were noted to determine the botanical composition of the pastures.

Duncan's new multiple range test (Steel and Torrie 1980) was used to compare differences in grazing times and biting rates between grazing periods. Regression analysis (Snedecor and Cochran 1971) was used to analyze relationships between grazing time, biting rate, and standing crop. Regression lines (both slopes and intercepts) for each trial were compared using procedures for testing homogeneity (Steel and Torrie 1980). All statistics were tested for significance at $\alpha=0.05$.

\section{Results}

\section{Grazing Time}

In trial 1, as available forage decreased from 417 to $203 \mathrm{~kg} / \mathrm{ha}$ during the 4 grazing periods (Table 1), animals increased their grazing times from a mean of $457.9 \mathrm{~min} /$ day during period 1 to $615.8 \mathrm{~min} /$ day during periods 3 and 4 . Grazing times for both trials are plotted in Figure 1. Regression analysis of the relationship between grazing time $(y)$ and forage availability $(x)$ showed a linear relationship $y=78.16-0.75 x,\left(r^{2}=0.76\right)$, with a standard error about regression $\left(S_{y \cdot x}\right)$ of $35.27 \mathrm{~min}$.

Grazing times increased throughout trial 2 (Table 1, Fig. 1). Grazing time was significantly and inversely correlated with forage availability. Regression procedures showed a linear relationship between grazing time $(y)$ and standing crop $(x)$ with $y=676.8-$ $0.3 x, r^{2}=0.71$, and $\dot{S}_{y x}=61.8 \mathrm{~min}$. Both intercepts and slopes were significantly different between trials.

During trial 1, there was no significant effect of cottonseed meal supplementation on grazing time. Grazing time (y) was significantly correlated with average plant height $(x)(\mathrm{cm})$ during trials 1 and 2. During trial 1 the relationship was described by the line $y=$

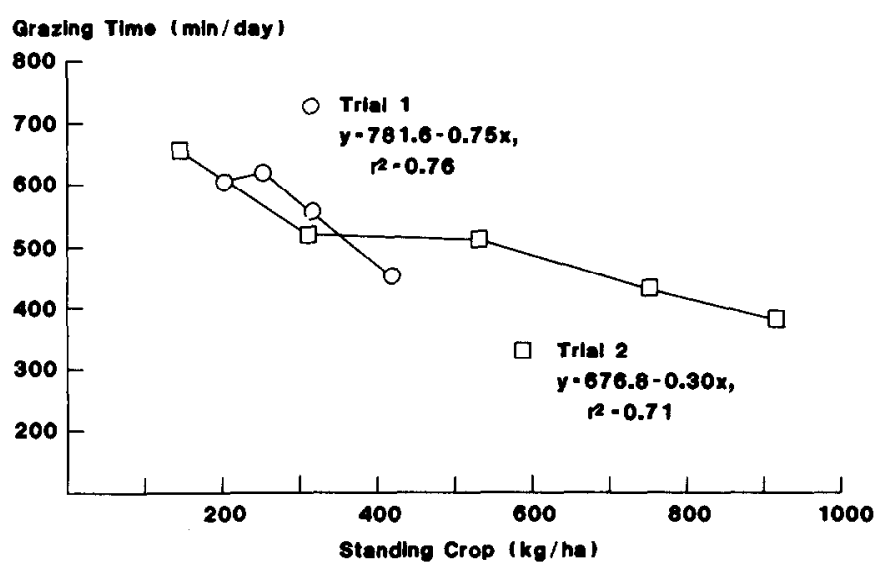

Fig. 1. Relationship between daily grazing time und standing crop for heifers grazing crested wheatgrass.

$802.8-24.2$, with $r^{2}=0.72$ and $S_{\mathrm{yx}}=38.33 \mathrm{~min}$. During trial 2, grazing time $(y)$ vs plant height $(x)$ was described by $y=720.3-$ $9.8 x$ with $r^{2}=0.70$ and $S_{y \cdot x}=62.62 \mathrm{~min}$.

Mean grazing times per $24 \mathrm{~h} \pm$ standard deviations average over all animals in each trial were $557.6 \pm 70.4$ min during trial 1 and $502.3 \pm 112.5 \mathrm{~min}$ during trial 2 . The overall trial means were significantly different. Only in trial 2 was there significant variation in grazing times among individual animals.

\section{Biting Rate}

Biting rate during trial 1 increased significantly from a mean of $54 \mathrm{bites} / \mathrm{min}$ in period 1 to $64 \mathrm{bites} / \mathrm{min}$ in period 4 . Biting rates are listed in Table 1 and plotted in Figure 2 . Biting rate during trial 1 was significantly and inversely correlated with standing crop (x) and described by $y=72.3-0.04 x$, with $r^{2}=0.40$ and $\dot{S}_{\mathrm{yx}}=4.35$ bites/min.

During trial 2, biting rates ranged from 37 to 50 and averaged 42 bites over the 5 periods (Table 1, Fig. 2). Biting rate (y) during trial 2 was significantly correlated with standing crop $(x)$ with $y=50.7$ $0.02 \mathrm{x}$ with $r^{2}=0.58$ and $S_{\mathbf{y} \cdot \mathbf{x}}=3.79 \mathrm{bites} / \mathrm{min}$. Both slopes and intercepts of biting rage/standing crop regressions were significantly different between trials.

Regression analysis of biting rate/forage availability and biting rate/plant height relationships during both trials showed linear relationships. Biting rate (y) was significantly correlated with plant height $(x)$ during both trials. During trial 1 the relationship was described by $\mathrm{y}=73.6-1.38 \mathrm{x}$, with $r^{2}=0.38$ and $\dot{S}_{\mathrm{yx}}=4.42$ bites $/ \mathrm{min}$. During trial 2, regression analysis yielded $y=53.3-$ $0.48 \mathrm{x}$ with $r^{2}=$ and $S_{\mathbf{y} \cdot \mathbf{x}}=3.44 \mathrm{bites} / \mathrm{min}$. Inclusion of forage

Table 1. Daily grazing time (min), standing crop (kg/ha), biting rate (bites/min), and weight change (kg) \pm standard deviationc of heifers grazing crested wheatgrass. All values are means over the dates listed. Means within trials followed by a common letter are not significantly $(P>0.05)$ different.

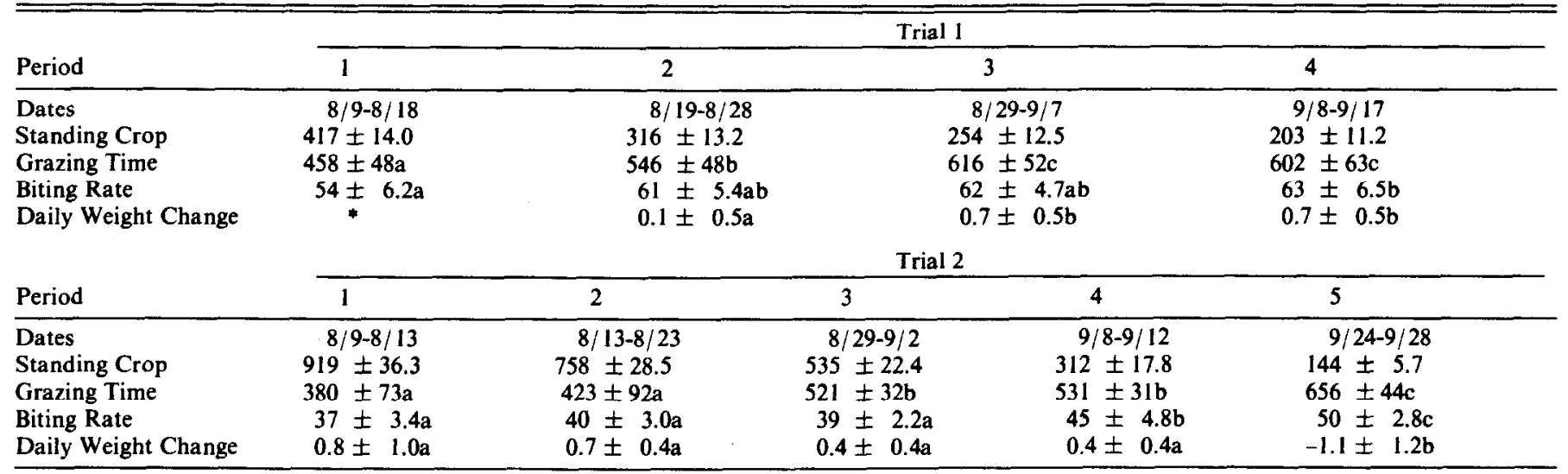

*Weights during this period were not recorded due to scale malfunction. 


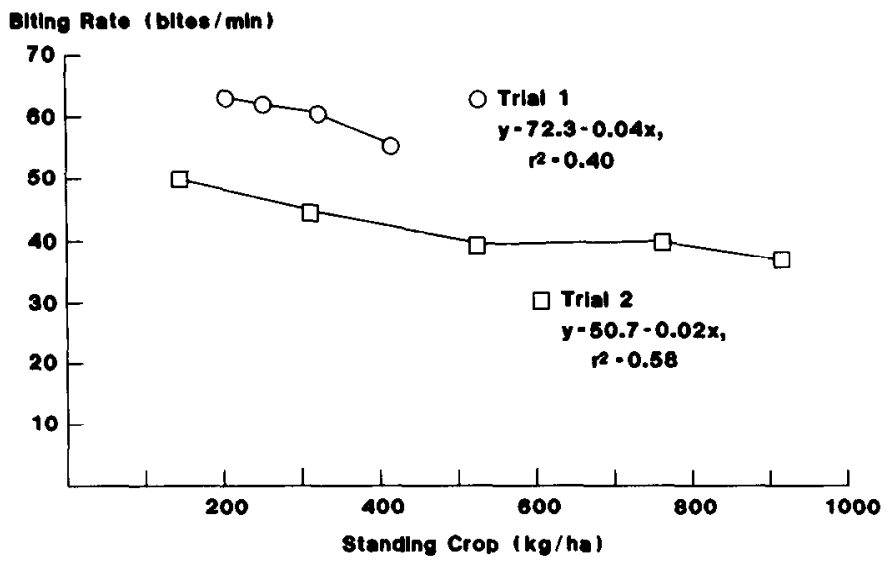

Fig. 2. Relationship between biting rate and standing crop for heifers grazing crested wheatgrass.

availability with plant height in a multiple regression equation added little or no predictive power.

Mean biting rates $( \pm S D)$ averaged over all animals in trial 1 was $59.6 \pm 5.5 \mathrm{bites} / \mathrm{min}$ compared with $42.6 \pm 5.8 \mathrm{bites} / \mathrm{min}$ during trial 2 . Mean biting rate was significantly different between trials.

Biting rates of individual animals were not significantly different in either trial. Protein supplementation had no significant effect on biting rate in trial 1 .

\section{Discussion}

Stobbs (1975) reported that fatigue limits the time spent grazing by a cow to about $720 \mathrm{~min} /$ day. Grazing time during the fifth period of trial 2 was only $9.4 \%$ less than this proposed maximum, suggesting that the heifers may have been grazing close to their potential maximum grazing time. A decrease in grazing time might be expected under a negative energy balance. Presumably, heifers might then conserve energy by restricting activities. There is no indication that a negative energy balance existed during either trial of the study; grazing time steadily increased as standing crop decreased (Fig. 1).

Grazing times at high standing crops may have been limited by nutritional or physiological factors including digestibility and rate of passage. Arnold (1964) indicated that intake is related to effects of forage digestibility on rumen function, as well as to forage availability. Nastis (1979) found that in vitro organic matter digestibility (IVOMD) declined from 40.2 to $32.9 \%$ between periods I and 5 of trial 2. Hodgson (1977) summarized data from several sources suggesting linear declines in herbage intake at digestibilities below $80 \%$. The low herbage digestibilities in the study likely limited intake and, consequently, grazing time during all periods in both trials. During trial 2, Nastis (1979) found no significant difference $(P>0.05)$ in daily organic matter intake between periods, although differences in intake were observed between individual animals. These findings suggest that individual animal intake may have reached a plateau and could not increase due to low digestibilities and slow rates of passage. Nastis (1979) also observed that mean IVOMD and mean crude protein content of forage were considerably higher $(49.3 \%$ vs $35.3 \%$ and $11.2 \%$ vs $6.8 \%$, respectively) during trial I than during trial 2 . Higher grazing times during trial 1 corresponded to higher digestibility, as well as lower standing crop.

The lack of a significant effect of protein supplementation on grazing time is consistent with findings of Box et al. (1965). They found no differences $(P>0.05)$ in total daily grazing time between cottonseed meal supplemented and unsupplemented cattle grazing shortgrass prairie in winter, although differences $(P \leqq 0.05)$ were observed in distances walked and rumination times.
Biting rate apparently depends on both quantity and quality of forage (Arnold 1964). The lowest biting rates were observed when forage was abundant during early periods in each trial. Highest biting rates were observed when forage was limited, and especially when there was green regrowth during periods 3 and 4 of trial 1 and period 5 of trial 2 (Table 1). This finding appears to contrast with the work of Stobbs (1974), who reported cattle biting rates of 50-80 bites/min for mature pasture and $45-63$ bites/min for leafy immature pasture. In that case, Stobbs observed that cattle grazing leafy green forage took large bites while bites were smaller but more frequent on mature pasture.

The maximum biting rate obtained in trial 2 was approximately $20 \%$ less than the maximum rate observed by Allden (1962) and Chacon and Stobbs (1976). Biting rate in trial 2 may have been limited by the patchier configuration of vegetation present in the pasture. Individual crested wheatgrass bunches were larger, coarser, and more widely spaced in trial 2 than in trial 1 , which probably produced the lower biting rates during trial 2, even when forage availability was comparable between years. The more uniform forage distribution during trial 1 resulted in less time being spent searching between bites. Uniformity of sward could be expected to have a major effect on biting rate.

Heifers apparently compensated for the decreased forage supply by increasing total bites per day. Using trial 2 results, total bites per day increased from 14,060 during period 1 to 32,800 during period 5 . In relative terms, grazing time increased $75 \%$ over the course of trial 2 , whereas biting rate increased only $35 \%$. In trial 1, grazing time increased $31 \%$ while biting rate increased $18 \%$.

The pattern of compensation was not uniform over all levels of forage availability. For example, in trial 2, as forage decreased grazing time increased but biting rate remained unchanged. As forage availability further declined grazing time continued to increase, but biting rate increased sharply. All trial 2 mean biting rates were below those observed in trial 1 . One would expect higher biting rates during period 5 of trial 2 because forage availability was lower than at the end of period 4 in trial 1.

Allden (1962) showed that biting rate of sheep increased to 65 bites/min when forage availability decreased to less than 1,000 $\mathrm{kg} /$ ha. Additionally, Chacon and Stobbs (1976) reported that maximum biting rate for cows was observed at minimum forage availability. In trial 2 of this study, biting rate did not change when standing crop decreased from 919 to $500 \mathrm{~kg} / \mathrm{ha}$; however, when standing crop declined below $500 \mathrm{~kg} / \mathrm{ha}$, biting rate increased. It can be concluded that on crested wheatgrass pastures, the maximum biting rate usually occurs at a lower standing crop than on tropical pastures. In general, it appears high biting rates are associated with low levels (e.g., $<600 \mathrm{~kg} / \mathrm{ha}$ ) of homogeneous green leafy herbage on temperate pastures. Because standing crops are usually greater, there is little information on tropical swards at these standing crops, although this relationship likely applies for tropical pastures as well. Higher availability of green forage results in larger but fewer bites per minute. The higher percentage of stem in mature forage likely reduces biting rates as selectivity becomes more pronounced. Animals grazing tropical pastures would be expected to show greater preference for leaf over stem because quality differences are of ten grcater on thesc pasturcs. Thus, biting rates on mature tropical swards would often be relatively low compared with biting rates on temperate swards because of the time required to select preferred leaf. With progressive defoliation, biting rates on tropical swards have been found to decrease (Stobbs 1974) while in our study progressive defoliation induced progressive increases in biting rate. During the latter stages of progressive defoliation, cattle were able to select preferred forage without being hindered by nonpreferred leaf and stem, which is often characteristic of mature tropical swards. Short, leafy regrowth was associated with high biting rates during both trials in our study.

We suggest that on crested wheatgrass pastures, forage availability is a preeminent factor affecting grazing time and biting rate. 
Also, it is likely that one or both of these grazing variables are affected by both animal and forage characteristics including leaf:stem stem ratio, forage maturity, forage homogeneity, forage height, forage density, rate of passage, rumen volume, and animal selectivity. Available forage may be correlated with grazing time and biting rate on a given pasture in a given year. Comparisons of these behavioral variables between years or between pastures will require multivariate models which include a variety of forage and animal characteristics.

\section{Literature Cited}

Allden, W.G. 1962. Rate of herbage intake and grazing time in relation to herbage availability. Proc. Aust. Soc. Anim. Prod. 4:163-171.

Arnold, G.W. 1960. The effect of the quantity and quality of pasture available to sheep on their grazing behaviour. Aust. J. Agr. Res. 11:1034-1043.

Arnold, G.W. 1964. Factors within plant associations affecting the behavior and performance of grazing animals. P. 133-154. In: D.J. Crisp, ed. Grazing in terrestrial and marine environments. Blackwell Scientific Publications, Oxford.

Arnold, G.W., and M.L. Dudzinski. 1978. Ecology of free-ranging domestic animals. Elsevier Scientific Publishing Co., Amsterdam.

Atkeson, F.W., A.O. Shaw, and H.W. Cave. 1942. Grazing habits of dairy cattle. J. Dairy Sci. 25:779-784.

Box, T.W., G. Brown, and J. Liles. 1965. Influence of winter supplemental feeding of cottonseed cake on the activities of beef cows. J. Range Manage. 18:124-126.
Chacon, E., and T.H.Stobbs. 1976. Influence of progressive defoliation of a grass sward on the eating behavior of cattle. Aust. J. Agr. Res. 27:709-727.

Church, D.C. 1971. Digestive physiology and nutrition of ruminants. Vol. 3. O.S.U. Bookstores, Inc., Corvallis, Ore.

Hafez, E.S.E. 1975. The behavior of domestic animals. 3rd ed. The Williams and Wilkins Co., Baltimore.

Hein, M.A. 1935. Grazing time of beef steers on permanent pastures. Amer Soc. Agron. 27:764-769.

Hodgson, J. 1977. Factors limiting herbage intake by the grazing animal. Proceedings of the International Meeting on Animal Production from Temperate Grassland. Dublin.

Hodgson, R.E. 1933. Influence of pasture management upon the grazing habits of cattle. J. Agr. Res. 47:417-424.

Nastis, A.S. 1979. Effects of forage availability on voluntary intake and feeding behavior of grazing heifers. Ph.D. Dissertation, Utah State University, Logan, Utah (Diss. Abstr. 40:3522-B).

Snedecor, C.W., and W.C. Cochran. 1971. Statistical methods. The Iowa State University, Press, Ames, lowa.

Steel, R.G.D., and J.H. Torrie. 1980. Principles and procedures of statistics, 2nd Ed. McGraw-Hill Book Co., New York.

Stobbs, T.H. 1970. Automatic measurement of grazing time by dairy cows on tropical grass and legume pastures. Trop. Grasslands. 4:237-244.

Stobbs, T.H. 1974. Rate of biting by Jersey cows as influenced by the yield and maturity of pasture swards. Trop. Grasslands 8:81-86.

Stobbs, T.H. 1975. Factors limiting the nutritive value of grazed tropical pastures for beef and milk production. Trop. Grasslands 9:141-150.

Wagnon, K.A. 1965. Social dominance in range cows and its effect on supplemental feeding. Calif. Agr. Exp. Sta. Bull. 819. 